\title{
NOT ALL OBJECT EXPERIENCERS ARE THE SAME: THE ROLE OF SE AND THE ARGUMENT STRUCTURE OF SERBIAN PSYCH VERB ANTICAUSATIVES
}

\author{
Peđa Kovačević*
}

\begin{abstract}
The goal of this paper is to account for the observation that some Serbian object experiencer anticausatives take instrumental NPs as expressions of the causer participant whereas others take $o d$ ('from')PPs. Following a number of authors (Alexiadou et al. 2013, Doron 2014, Anagnostopoulou \& Samioti 2014, a. o.), I assume that differences in the licensing of expressions introducing event participants point in the direction of structural differences in terms of presence/absence of certain layers of verbal structure. The observed difference is accounted for by assuming that instrumental NPs are syntactically licensed by VoiceP while $\operatorname{od}($ ' 'from')-PPs are rejected by VoiceP owing to a semantic clash. Consequently, full VoiceP structure is present with psych verb anticausatives that license instrumental NPs and absent with psych verb anticauatives that license $o d$ ('from')-PPs. The analysis presented in the paper has implications for the syntactic and semantic status of SE as well. It is suggested that Chierchia's (2004) reflexive approach to anticausatives can be extended to psych verb anticausatives which license instrumental NPs whereas the standard approach (Schäfer \& Vivanco 2016) should be retained for typical anticausatives with inanimate internal arguments and object experiencers that license $o d$ ('from')-PPs. Such a "middle-ground" solution follows from the syntactic structures I propose for these two different sets of psych verb anticausatives.
\end{abstract}

Keywords: anticausatives, psych verbs, experiencers, argument structure

\section{Introduction}

Extensive research into the syntactic and semantic properties of psych verbs over the past several decades reveals that this class of verbs is special and exceptional in a number of respects primarily in the domain of argument structure and $\theta$-role assignment (Belletti \& Rizzi 1988, Pesetsky 1994, Landau 2010, a. o.). Recent approaches to argument structure within Distributed Morphology (Halle \& Marantz 1993) rely on the evidence from licensing of different kinds of PPs and NPs expressing event participants in order to broach the presence/absence of certain layers of verbal structure in verbal and adjectival participles and nominalizations (Alexiadou et al. 2009, Alexiadou et al. 2013, Doron 2014, Anagnostopoulou \& Samioti 2014, a. o.).

Against this research background, I approach the issue of the distribution of two different morphosyntactic expressions of the stimulus/causer participant with psych verb $S E$ anticausatives in Serbian. In particular, I will show that object experiencers fall into two main categories when it comes to the morphosyntactic shape of the stimulus/causer participant that they license under $S E$ anticausativization. One group of object experiencer anticausatives licenses $\operatorname{od}($ ('from')-PPs (1a) whereas the other combines with instrumental case-marked bare NPs (there are also verbs that seem to oscillate between these two typical cases) (1b).

\footnotetext{
*University of Novi Sad, pedjakovacevic90@gmail.com.

Bucharest Working Papers in Linguistics XXII, 1, 77-96, e-ISSN 2392-8093, ISSN-L 2069-9239 DOI: 10.31178/BWPL.22.2.4
} 


a. Jovan se razbesneo od bratovog ponašanja
Jovan SE angered from brother's.GEN behavior.GEN
'Jovan got angry from his brother's beahvior'
b. Jovan se šokirao bratovim ponašanjem
Jovan SE shocked brother's.INST behavior.INST
'John got shocked by his brother's behavior'

In light of the assumption that different expressions of event participants need to be properly licensed by the appropriate layer of verbal structure, these differences in the licensing of instrumental NP/NPs expressing cause and $\operatorname{od}($ 'from')-PPs will be taken as indications of the differences in the presence of verbal functional structure with $S E$ anticausatives. Those anticausatives that license instrumental NPs and reject $\operatorname{od}$ ('from')PPs (1b), even though different from proper agentive reflexives, will nonetheless, be analyzed as akin to them in terms of the presence of a special kind of VoiceP layer, which licenses instrumentals and prohibits od('from')-PPs. On the other hand, those anticausatives that license od('from')-PPs and prohibit instrumentals (1a) will be analyzed as lacking the VoiceP layer and having a pure anti-causative semantics. Finally, it will be argued that the thematic roles of the experiencer arguments with these two types of object experiencers are not identical either.

The analysis presented in the paper will have implications for the syntax and semantics of the $S E$ anticausativizer, whose status is a matter of controversy in the literature. One point of view, originally due to Chierchia (2004), holds that $S E$ always has reflexive semantics while the mainstream position seems to be that it can play the role of a pure anticausativizer (i.e. external argument removal) in addition to being a reflexivizer (Schäfer \& Vivanco 2016). Based on the account of two different classes of object experiencer anticausatives I will present in this paper, I will propose a middle ground solution whereby reflexive semantics is not restricted to typical reflexive uses only while at the same time, there are cases where $S E$ does have a pure anticausative semantics. This middle ground solution also avoids some of the pitfalls of Chierchia's (2004) analysis identified by Schäfer \& Vivanco (2016) while retaining its basic intuition concerning the link between reflexive and anticausative forms of $S E$.

\section{Background}

Psych verbs or experiencer verbs have attracted a lot of attention in the linguistic literature, particularly over the last three decades. Baker's (1988) hypothesis that thematic roles are fully determined by the structural relationships between the verb and its arguments spurred the interest in psych verbs because this class of verbs seems to represent a systematic exception to the rule about one-to-one mapping between thematic roles and structural positions. At first glance, the pairs of sentences in (2) could be taken as an immediate falsification of Baker's (1988) hypothesis. In (2a), the NP carrying the thematic role of experiencer is located in the subject position while the same NP with 
(apparently) the same thematic role appears in the object position of the (apparently) same verb.

(2) a. Peter worries about the pandemic.

b. The pandemic worries Peter.

The conceptual appeal of Baker's (1988) Uniform Theta Assignment Hypothesis (UTAH) compelled many linguists to look for ways in which this approach could be salvaged in the face of such empirical challenges. Belletti \& Rizzi's (1988) work on Italian psych verbs paved the way for this line of thinking. For instance, they observed that in addition to exhibiting exceptional behavior when it comes to $\theta$-role assignment, these verbs also have anomalous binding patterns. The sentence in (3a) shows that the experiencer argument in the object position can bind the anaphor in the subject position, which is impossible with other classes of verbs (3b):
a.
Questi pettegolezzi su di se preoccupano Gianni più these pieces of gossip about himself worry Gianni more di ogni altra cosa than anything else
b. *Questi pettegolezzi su di se descrivono Gianni meglio di these pieces of gossip about himself describe Gianni better than ogni biografia ufficiale any official biography

(Belletti \& Rizzi 1988: 312)

Therefore, not only do psych verbs challenge Baker's (UTAH), but they also seem to contradict the Binding Theory, another cornerstone of Generative Grammar (Chomsky 1993). However, Belletti and Rizzi (1988) show that it is possible to retain both the Binding Theory and UTAH in the face of the challenge from psych verbs at one stroke. They propose an analysis of object experiencers whereby the theme subject is located in the $\mathrm{V}^{0}$ complement position at D-Structure, like other theme arguments, where it is ccommanded by the experiencer argument, which starts off in Spec VP. The theme argument moves to Spec IP/TP at S-Structure, which is how it ends up in the subject position. This analysis explains the anomalous behavior of psych verbs with respect to reflexive binding and $\theta$-role assignment without challenging either the Binding Theory or UTAH.

From a crosslinguistic perspective, psych verbs exhibit an entire array of idiosyncratic properties, which Landau (2010) terms "psych effects". One interesting property of these verbs in relation to argument structure manifests itself in English with respect to causative alternation (Levin 1993). Namely, unlike other causative transitive verbs, object experiencer verbs do not participate in the causative alternation. For instance, a typical transitive verb such as open (4a) can also be used as a kind of unaccusative intransitive (4b). This is not possible with object experiencers (5). 
(4) a. Peter opened the door.

$\begin{array}{lll} & \text { b. The door opened. } \\ \text { (5) } & \text { a. The noise annoyed Peter. }\end{array}$

b. $\quad$ PPeter annoyed.

Alexiadou \& Iordăchioaia (2014), however, observe that the lack of causative alternation with object experiencers is subject to crosslinguistic variation as such alternations are grammatical in both Greek and Romanian (6-7). For that reason, these authors explain the lack of causative alternation with object experiencers in English as a peculiarity of English syntax arising as a result of an interplay of diachronic factors. In support of their conclusion, Alexiadou \& Iordăchioaia (2014) point out the fact that causative alternation with object experiencers was present in the earlier stages in the development of the language.

(6) a. $\mathrm{O}$ Janis enohlise ti Maria epitides /me ena bastuni. Greek the Janis annoyed the Maria intentionally/with a stick

'Janis annoyed Maria intentionally/with a stick.'

b. O Janis enohlithike (*epitides /*me ena bastuni) me the Janis annoyed.NACT intentionally/ with a stick with to pehnidi

Greek the game

'Janis got annoyed with the game.'

(Alexiadou \& Iordăchioaia 2014: 54)

a. Ion a enervat-o pe Maria dinadins /cu un băț. Romanian Ion has annoyed-her PE Maria intentionally/with a stick 'Ion annoyed Maria intentionally/with a stick

b. Maria s-a enervat (pe Ion) de la joc (*dinadins

Maria REFL-has annoyed (at John) of at game (intentionally

/*cu un băţ)

/with a stick)

Romanian

'Maria got annoyed (at John) from the game.'

(Alexiadou \& Iordăchioaia 2014: 54)

What the examples in (6) and (7) also show is that there seems to be a crosslinguistic difference in the way in which the stimulus participant ${ }^{1}$ is expressed under causative alternation. In the Greek example (6b), the stimulus participant, me to pehnidi 'with the game' is realized in the form of a PP headed by the same preposition that introduces instruments in the transitive version of the same verb as in the phrase me ena bastuni 'with a stick' (6a). In contrast, Romanian uses a different phrase for this same

\footnotetext{
${ }^{1}$ I am using the term "stimulus participant" as a cover term for the non-experiencer participant in the eventuality denoted by the psych verb given the fact that this participant can have different syntactic realizations and thematic roles. According to Pesetsky (1994), this participant can have the $\theta$-role of theme, causer, target and subject matter. I use this term in order to abstract away from its exact syntactic and semantic role.
} 
participant, namely, de la joc 'from the game' (7b), which is different from the PP that introduces the instrument, cu un bat 'with a stick' (7a).

In Serbian, object experiencers also participate in the causative alternation (8). As is apparent from the example in (7b), the stimulus participant is expressed by means of an instrumental case-marked bare NP. ${ }^{2}$ Physical instruments take the same morphosyntactic form (9). Therefore, the behavior of object experiencers in Serbian is similar to what we saw in Greek.
a. Njegov brat je zaprepastio Jovana svojim ponašanjem
His brother AUX amazed/dazzled Jovan self's.INST behavior.INST
'Jovan's brother amazed/dazzled him with his behavior.'
b. Jovan se zaprepastio bratovim ponašanjem
John.NOM SE amaze brother.INST behavior.INST
'John got amazed by his brother's behavior.'
(9) Njegov brat je iznervirao Jovana štapom ${ }^{3}$
His brother AUX annoyed Jovan stick.INST
'Jovan's brother annoyed him with a stick'

On the other hand, it appears that the instrumental case-marked bare NP as the expression of the stimulus participant under psych verb causative alternation is not the only option in Serbian. The verb razbesneti 'anger' requires an instrumental case-marked bare NP as an expression of the stimulus participant in its transitive version (10a). However, under causative alternation, it requires an $\operatorname{od}($ 'from')-PP with a genitive casemarked bare NP in its complement (10b). In other words, it behaves rather like the verb in the Romanian example (7b).
a. Njegov brat je razbesneo Jovana svojim ponašanjem
His brother AUX angered Jovan self's.INST behavior.INST
'Jovan's brother angered him with his behavior'
b. Jovan se razbesneo od bratovog ponašanja
Jovan.NOM SE anger from brother's behavior.GEN
'Jovan got angry from his brother's behavior'

There are reasons to believe that these differences in the morphosyntactic realization of the stimulus participant under causative alternation are not trivial and that they reveal underlying structural/semantic differences. I would argue that this is, in fact, the null hypothesis for Serbian given that it apparently employs two different options with

\footnotetext{
${ }^{2}$ I will be referring to nominal expressions in Serbian as NPs assuming with Bošković $(2005,2012)$ and many others that Serbian, as a language without articles does not project the DP layer. However, no part of the argument in this paper will hinge on this assumption.

${ }^{3}$ I am using a different verb here because the verb iznervirati 'annoy' allows concrete instruments more readily than the verb zaprepastiti 'amaze/dazzle'. It is easier to annoy someone with a stick than to dazzle them with a stick. I did not use the verb iznervirati 'annoy' in the initial example in (7) because it exhibits a more ambiguous behavior with regard to the expression of the stimulus participant than the verb zaprepastiti 'dazzle' as will be shown in section 3 .
} 
different verbs. Learnability considerations suggest that the system tends towards reducing unnecessary complexity. In that sense, one would be hard pressed to explain why a language would use two different morphosyntactic structures to express one and the same thing.

The recent literature on verbal and adjectival participles and nominalizations also suggests that these different ways of marking the stimulus participant with psych verb anticausatives point in the direction of deeper structural differences. Assuming Distributed Morphology (Halle \& Marantz 1993) or some other version of the neoconstructionist approach to syntax/morphology, derivational paradigms of verbs are expected to share some degree of verbal structure with the verb itself. Kratzer (1996, 2000) argues that German adjectival passives are different from verbal passives in that they lack the VoiceP. In (11a), the adjectival passive is compatible with the reading where the children washed themselves, while this reading is unavailable with the verbal passive in (11b). Kratzer (2000) takes this as evidence that an implicit agent argument introduced by VoiceP is present with the verbal passive and absent with the adjectival passive.

a. Die Kinder sind (*immer noch) gewaschen.
the children are still washed
b. Die Kinder sind gewaschen worden.
the children are washed gotten
'The children have been washed.'

(Kratzer 2000: 4)

Unlike (most) adjectival passives, verbal passives are also capable of licensing byphrases, a fact which has been taken as an indication that they contain VoiceP (see Kratzer 2000). This neat division between verbal and adjectival passives in terms of byphrase licensing has been challenged recently but the idea that by-phrases are licensed by Voice has been kept (Gehrke 2013, Alexiadou et al. 2013).

The hypothesis that the licensing of by-phrases can provide insight into the presence of the higher layers of the extended VP inspired an entire current of research that uses the distribution of various elements introducing event participants (and modifiers) to broach the presence of functional structure in verbal constructions, participles and nominalizations (Alexiadou et al. 2009, Alexiadou et al. 2013, Doron 2014, Anagnostopoulou \& Samioti 2014, a. o.).

According to Alexiadou et al. (2009), PPs/DPs introducing event participants are licensed either structurally (presence/absence of functional structure) or semantically (the compatibility of the meaning of the preposition and the meaning of the root in question). In light of this line of research, the observation that in Serbian, different psych verb anticausatives license different morphosyntactic expressions introducing the stimulus participant suggests that these verbs might actually have different internal syntactic structures.

In this paper, I will use the availability of instrumental NPs and $\operatorname{od}($ 'from')-PPs introducing event participants with SE anticausatives of psych verbs in Serbian to gain insight into the presence of verbal functional structure. It will be argued that these differences in PP/NP licensing reveal the non-homogenous nature of object experiences in 
terms of their semantic roles and syntactic behavior. More specifically, I will take the licensing of instrumental case-marked bare NPs as a signal of the presence of VoiceP while the licensing of $\operatorname{od}($ 'from')-PPs will be taken as a sign of the lack of this layer of structure. Furthermore, it will be suggested that the syntactic and semantic role of the experiencer argument is also different with these two kinds of verbs.

\section{The problem}

On the surface, all object experiencers in Serbian appear the same. As in most other languages, object experiencers are typically eventive. They allow agentive subjects, and the experiencer argument takes accusative case (12). They also allow causer subjects (13).

(12) Petar je zaprepastio/osramotio /razbesneo/ohrabrio Jovana Peter.NOM AUX amazed /embarrassed/annoyed /encouraged Jovan.ACC 'Petar embarrassed/annoyed/encouraged Jovan.'

(13) Petrovo ponašanje je zaprepastilo/osramotilo/razbesnelo/ohrabrilo Peter's behavior.NOM AUX amazed /embarrassed/annoyed /encouraged Jovana

Jovan. ACC

'Peter's behavior amazed/embarrassed/annoyed/encouraged John'

Under $S E$-anticausativization, they never allow od strane('by')-PPs introducing the agent argument (14).
a. $\quad$ Jovan se zaprepastio od strane brata
$\begin{array}{llll} & \text { Jovan.NOM SE amaze by broth } \\ \text { b. } & \text { *Jovan } & \text { se razbesneo od strane brata }\end{array}$
$\begin{array}{llll}\text { Jovan.NOM } & \text { SE amaze } & \text { by brother.GEN } \\ \text { *Jovan } & \text { se razbesneo } & \text { od strane brata }\end{array}$ Jovan.NOM SE anger by brother.GEN
c. *Jovan se ohrabrio od strane brata Jovan.NOM SE encourage by brother.GEN
d. *Jovan se osramotio od strane brata Jovan.NOM SE embarrassed by brother.GEN

In Serbian, causers are normally introduced by $\operatorname{od}($ 'from')-PPs and they are compatible with SE anticausatives (15):

(15) Vrata su se otvorila od vetra

door AUX SE open from wind.GEN

'The wind opened the door'

Instrumental case-marked NPs can also be used but typically with animate subjects. In those cases, the output is ambiguous between an agentive reflexive reading and an involuntary reading which still has agentive properties. The instrumental NP seems to play the role of an instrument causer in both cases (16): 
(16) Jovan se povredio nožem

Jovan.NOM SE hurt knife.INST

'Jovan' (intentionally) hurt himself with a knife'

Instrumental NP causers are available with inanimate subjects (17) but these uses are limited to very specific meanings:

(17) Kanal se napunio smećem

canal SE filled garbage.INST

'The canal got filled with garbage'

With object experiencer psych verbs under $S E$-anticausativization, we observe the pattern in (18):
a.
Jovan se zaprepastio bra
Jovan.NOM SE amaze
bratovim ponašanjem /??od
bratovog ponašanja
brother's behavior.GEN
'Jovan got amazed by his brother's behavior'
$\begin{array}{llll}\text { b. Jovan } & \text { se razbesneo *sestrinim ponašanjem /od sestrinog } \\ \text { Jovan.NOM SE anger sister's.INST } & \text { behavior.INST/from sister's }\end{array}$
ponašanja
behavior.GEN
'Jovan got angry from his sister's behavior'
ponašanja
behavior.GEN
'Jovan encouraged himself with his brother' behavior/
c. Jovan se ohrabrio bratovim ponašanjem /od bratovog
Jovan.NOM SE encourage brother's.INST behavior.INST/from brother's
Jovan got encouraged by his brother's behavior.'
d. Jovan se osramotio svojim ponašanjem /*od svog
Jovan.NOM SE embarrass self's.INST behavior.INST/ from self's
ponašanja
behavior.GEN
'Jovan embarrassed himself with his behavior'

Some of these $S E$ anticausatives allow instrumental NPs but not $\operatorname{od}$ (from)-PPs (18a). Others allow only od-PPs but not instrumental NPs (18b), while others still license both instrumental NPs and $o d$-PPs (with varying degrees of acceptability) (18c). Finally, some of these verbs allow instrumental NPs but only under a reflexive-like reading (18d).

It is difficult to account for these discrepancies assuming full structural/semantic uniformity with these different verbs. Again, from the learnability perspective, it is hard to explain why a language would resort to this complication unless there were some important syntactic and semantic reasons to do so. We know that the licensing of by-phrases with verbal/adjectival participles can tell us whether a verb projects the VoiceP 
layer. However, what can we conclude about the internal functional structure of a psych verb if the $S E$ anticausative that is derived from it licenses an instrumental NP but rejects $o d($ 'from')-PP as an expression of the stimulus participant? In order to answer this question in a meaningful way, we first need to clarify what the distribution of causer PPs and NPs in (18) tells us about the structure of the verbal domain. We also need to make some assumptions about the syntactic and semantic role of $S E$ with anticausatives to make sense of these data. This will be the task of the next section.

\section{Breaking down the problem}

\subsection{Licensing of $\operatorname{od}\left({ }^{\prime}\right.$ from')-PPs and instrumental NPs}

In order to determine the diagnostic value of instrumental NPs and $\operatorname{od}($ 'from')-PPs, it is necessary to examine their distribution with different types of verbs outside the class of psych verbs. $\operatorname{Od}($ 'from')-PPs are incompatible with agentive constructions (19):

$$
\begin{aligned}
& \text { *Jovan je polomio prozor od udarca } \\
& \text { Jovan AUX broke window from punch.GEN } \\
& \text { 'Jovan broke the window with a punch of his hand.' }
\end{aligned}
$$

Sometimes, it is possible to use the $o d$ ('from')-PP in what would seem like an agentive expression, but the effect of this item in such cases is to cancel the subject's agentivity and the sentence becomes incompatible with adverbials signaling intentionality (12). Traditional grammars refer to this use of $\operatorname{od}$ ('from')-PPs as an expression of overwhelming force or an external cause that overpowers the agent (Piper et al. 2005).

$$
\begin{aligned}
& \text { Jovan je (*namerno) razbio čašu od straha } \\
& \text { Jovan AUX intentionally broke glass from fear.GEN } \\
& \text { 'Jovan broke (intentionally) broke the glass out of fear' }
\end{aligned}
$$

Therefore, od ('from')-PPs cannot introduce an intervening cause/instrument nor a cause that precedes the agent as the primary cause. If they are combined with an animate subject that could potentially be interpreted as an agent, they relegate it to the level of an intermediary link in a chain of causation thereby negating its status as an agent. In other words, $\operatorname{od}$ ('from')-PPs seem to compete with agents for the status of the primary cause.

At the same time, it is quite clear that unlike agent by-phrases, od('from')-PPs need not be structurally licensed because they can appear in adjectival predicates so long as they are compatible with the meaning of the predicate itself on the basis of world knowledge (21). In sum, od('from')-PPs are semantically licensed and, also, semantically incompatible with agents.

(21) Bokser je bio plav od protivnikovih udaraca $/ *$ od strane protivnika boxer AUX BE blue from opponent's punches/ by the opponent 'The boxer was all bruised from the opponent's punches/by the opponent.' 
Working under the assumption that structural explanations are to be preferred over the lexical or semantic ones where possible, I will commit myself to the idea that other event expressions introducing event participants (instrumental NPs, od strane('by')-PPs, etc.) are structurally licensed given the fact that it is not possible to find cases where they combine with structures where one cannot plausibly argue for the existence of any kind of verbal structure. In (21), the $o d($ 'from')-PP combines with a pure descriptive adjective making a structural explanation impossible, which is why semantic licensing becomes the only viable option.

Turning to instrumental PPs, it seems that they always introduce the meaning of an intermediary link in a chain of causation with an agent as the primary cause. In Wolff's (2003) terminology, this is the semantic description of an instrument. They are compatible with both reflexives and anti-causatives as long as they allow for an instrument-like participant.

The example in (17) repeated here as (22a) illustrates this quite well. In this example, even though we have what appears to be like a theme subject, the instrumentalmarked NP is acceptable because garbage was indeed 'instrumental' in the event of filling up the canal. Using Ramchand's (2008) terminology, it is possible to say that it participated in the process component of the filling up event rather than merely initiating the event. This is precisely the reason the $o d($ 'from')-PP is unacceptable in this context. An $o d$ ('from')-PP denotes a completely external primary cause that merely sets off the event. If one imagines a scenario in which the garbage is interpreted as an initiating cause of the filling up event rather than being instrumental in it, the sentence in (22b) improves.

$$
\begin{aligned}
& \text { a. Kanal se napunio smećem } \\
& \text { canal SE filled garbage.INST } \\
& \text { 'The canal got filled with garbage' } \\
& \text { b. ??Kanal se napunio od smeća } \\
& \text { canal SE filled from garbage.GEN }
\end{aligned}
$$

I take this to mean that instrumental NPs have the meaning of an intervening entity in a causation chain (i.e. an instrument). Wolff (2003) makes the argument that intervening entities do not break the chain of direct causation only when the primary cause is an agent. He illustrates the importance of this point with an example that I will paraphrase here. Suppose a person named Bill opens a window in order to let some air into the room, but a gust of wind blows into the room and opens the door. In that case, saying that Bill opened the door would be infelicitous. It would be better to say Bill caused the door to open. Now, suppose the same person were a captive in a room where they could not open the door any other way but by somehow opening the window and letting a gust of wind into the room, and they manage to achieve that eventually. In that case, it would suddenly become much more appropriate to say that Bill opened the door, and Wolff's (2003) experimental finds support this contrast. The way Wolff (2003) interprets these facts is by assuming that lexical causative verbs can be used only to denote direct causal chains. Direct causal chains, in turn, exist if there is no intervening entity between the initial cause (Bill in this example) and the final causee (the door) or if the intervening entity is not an autonomous cause but an enabler of the primary cause. 
The intervening entity can count as an enabler only if the initial cause has the tendency towards the final outcome, and the achievement of this final outcome is enabled by the intervening entity. The typical case when the initial cause has a tendency towards the final outcome is when it is an agent that intends the outcome. This is why, in the given example, it is possible to say that Bill opened the door only if he actually wanted to open it by harnessing the power of the wind, and the wind enabled him to do so.

Wolff's (2003) terminological inventory is important for our purposes here because I want to suggest that all instances of the causal use of instrumental NPs name enabling entities (or instruments in semi-colloquial terms). What this means is that the licensing of an instrumental NP in a given construction entails the existence of a primary cause whose tendency towards the final outcome is enabled by the entity denoted by the instrumental NP. Most of the time, this primary cause with a tendency towards the final result will be the agent, but I would like to suggest that it does not necessarily have to be the agent in the traditional sense so long as it has a tendency towards the final result. Consider also (23) where the subject is clearly not an agent, and yet the instrumental NP (but not $\operatorname{od}$ ('from')-PP) is still licensed because it conforms to the definition of an 'enabler' in Wolff's (2003) terminology:

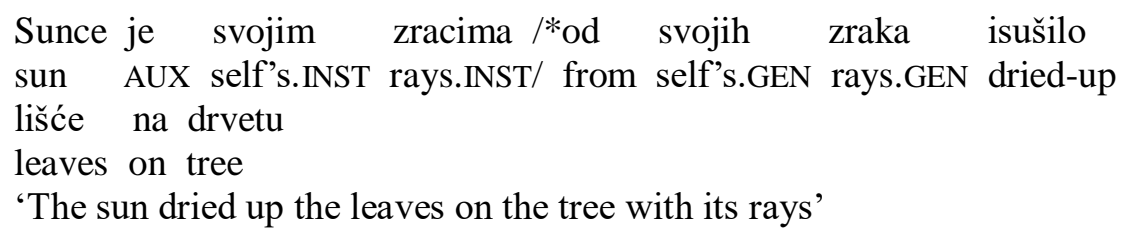

I should point out at this point that Wolff's (2003) approach to causation is not directly translatable to any generative view of argument structure. Wolff's (2003) work is couched in Talmy's (1988) model of force dynamics, and its primary aim is to capture the choice of lexical items and phrases as expressions of different causation patterns. While it gives no predictions about argument structure, Wolff's (2003) approach provides us with a quite precise way to define agents and instruments, which is important for our purposes here. Agents would basically be those primary causers that retain the status of direct causers even in the presence of intervening entities (instruments). In other words, agents would be understood as primary causes whose tendency towards some effect is enabled by an intervener. By the same token, instruments would be intervening entities that enable the primary cause to create the effect it tends towards. It is crucial to stress that the traditional notion of an agent becomes just a subspecies of a broader concept of a primary direct causer, which can also include inanimate entities that can project tendencies (e.g. the sun, the wind, etc.).

Based on these considerations, I would hypothesize that, in structural terms, this primary cause with a tendency towards the final outcome whose existence is entailed by the presence of an instrumental NP can be represented using the familiar notion of agent located in Spec VoiceP. From this vantage point, I would argue that instrumental NPs encoding the instrument or enabler are licensed by the presence of VoiceP in the structure while $\operatorname{od}$ ('from')-PPs are licensed semantically but rejected in the context of VoiceP because its semantics clashes with the semantics of the primary cause hosted by VoiceP. 


\subsection{The role of $S E$}

Having specified the diagnostic value of instrumental NPs and $\operatorname{od}($ 'from')-PPs, it is necessary to determine the syntactic and semantic contribution of $S E$ with psych verb anticausatives in order to make sense of the initial puzzle concerning the distribution of these two means of expressing the stimulus participant. In the context of Serbian, Marelj (2004) analyzes $S E$ as a morphological exponent of a syntactic arity operation on the Theta Grid whereby the external argument is removed and the accusative case absorbed. She relies of Reinhart's $(2000,2003)$ lexicalist approach to argument structure known as the Theta System, but she nonetheless views $S E$ as a syntactic element. In that sense, the contribution of SE with anticausative verbs is best analyzed as syntactic regardless of whether one starts off from a neo-constructionist or from a lexicalist approach to argument structure.

In terms of the semantic contribution of $S E$, while some authors have argued that it always carries a reflexive-like meaning (Chierchia 2004), others have tried to analyze it as merely signaling the lack of an external argument (see Schäfer \& Vivanco 2016). For Chierchia (2004), the presence of SE, in languages that have this morphological item, is always a signal of the same reflexive-like semantics, which results in proper reflexivity when it is combined with an agent. However, it can also be combined with a causer, and in that case, it triggers the meaning of a causer acting upon itself, which would be a rough paraphrase of the semantics he proposes for anticausatives. On the other hand, Schäfer \& Vivanco (2016) argue that the reflexive use of $S E$ is separate from the anticausative one, and with anticausatives, it merely signals the lack of external argument and an unspecified cause. I will pick up on this debate in section 5, where I will propose a sketch of an account that promises to reconcile the two positions in a principled manner.

\subsection{Back to object experiencers under anticausativization}

Recall that there are verbs that license $\operatorname{od}($ 'from')-PPs but not instrumental NPs, those that allow only instrumental NPs and not $\operatorname{od}($ 'from')-PPs and those that allow both (18 repeated here as 24$)$.
a. Jovan
se zaprepastio bratovim
ponašanjem /??od bratovog
Jovan.NOM SE amaze brother.INST behavior.INST/ from brother's ponašanja behavior.GEN
'Jovan got amazed by his brother's behavior'
b. Jovan se razbesneo *sestrinim ponašanjem /od sestrinog Jovan.NOM SE anger sister's.INST behavior.INST/from sister's ponašanja behavior.GEN
'Jovan got angry from his sister's behavior' 
c. Jovan se ohrabrio bratovim ponašanjem /od bratovog Jovan.NOM SE encourage brother's.INST behavior.INST/from brother's ponašanja behavior.GEN

'Jovan encouraged himself with his brother' behavior/Jovan got encouraged by his brother's behavior'

d. Jovan se osramotio svojim ponašanjem /*od svog Jovan.NOM SE embarras self's.INST behavior.INST/ from self's ponašanja behavior.GEN

'Jovan embarrassed himself with his behavior'

What these data show immediately is that those verbs that license instrumental NPs but not $o d$ ('from')-PPs are not all identical. While (24d) allows only a purely reflexive reading as evidenced by the ungrammaticality of (25) (even though the sentence is compatible with an involuntary reading), (24a) is less clearly reflexive and more akin to a typical anticausative reading, and yet, it still licenses instrumental and rejects an $\operatorname{od}($ 'from')-PP, which are both indications of the presence of an agent-like argument.

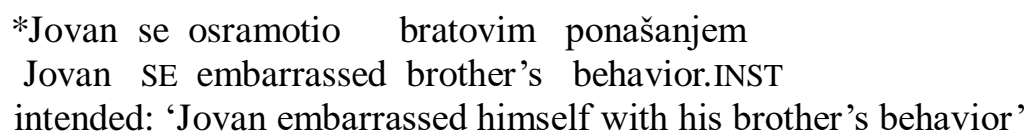

Verbs like (24b), on the other hand, are clearly not reflexive as they do not allow instrumental NPs, and they accept $\operatorname{od}($ 'from')-PPs. Finally, there are verbs which seem to accept both instrumental NPs and $o d$ ('from')-PPs (24c), but the choice of an instrumental NP or an $\operatorname{od}($ 'from')-PP triggers a difference in meaning, whereby a sentence with an instrumental NP creates a more reflexive-like reading as opposed to a sentence with an $o d$ ('from')-PP, which results in an anticausative interpretation. I will assume that these verbs oscillate between the two prototypical cases in (24a) and (24b) and will not treat them as a separate class.

One more peculiarity of the verbs that allow $\operatorname{od}($ 'from')-PPs but not instrumental NPs is to be noted here. Namely, unlike the other verbs in (24), verbs such as razbesneti 'anger' allow target of emotion $\theta$-role to be expressed (26) under SE anticausativization.

Jovan se razbesneo na brata

John SE angered at brother.ACC

'John got angry at his brother'

However, causative/agentive predicates with the same verb disallow the expression of the target $\theta$-roles (27) as observed by Pesetsky (1996) for English.

a. *Brat je razbesneo Jovana na majku brother AUX angered Jovan.ACC on mother.ACC intended: *'His brother angered Jovan at his mother' 

b. *Batovo ponašanje je razbesnelo Jovana na njega brother's behavior AUX anger Jovan. ACC at him intended: *'His brother's behavior angered Jovan at him.'

Also, in Serbian, the referent of the NP expressing the target $\theta$-role cannot be equated with the causer argument as many causers are unacceptable as target (28):

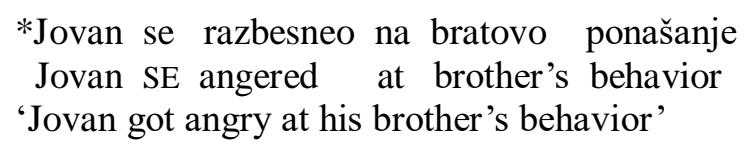

If causers and agents cannot occur together with target (27), but a target is fine in the anticausative version with $S E$ (26), we can conclude that the anticausative version of this verb does not contain the semantic component/layer of syntactic structure that creates a clash with the target participant in the transitive version.

In summary, there are several crucial empirical observations we need to account for. First, object experiencer verbs differ in the kinds of expressions introducing the stimulus participant that they license. Some of them license instrumental NPs; others license $\operatorname{od}($ ' (from')-PPs, and others still tolerate both with slight variations in meaning. Second, $\operatorname{od}$ ('from')-PPs are illicit in the presence of an agent. This clash between $\operatorname{od}($ 'from')-PPs and agents can be attributed to the fact that $\operatorname{od}($ 'from')-PPs include the semantics of primary as well as direct cause, which is present with agents as well. Third, even though instrumental NPs are generally licensed by the presence of an agent and $o d$ ('from')-PPs are rejected in the presence of an agent, there are verbs which license instrumental NPs and reject $o d$ ('from')-PPs without having a real agent. Fourth, those psych verb anticausatives that license $\operatorname{od}$ ('from')-PPs only tend to allow a target $\theta$-role, while others do not. Fifth, the target $\theta$-role is incompatible with causers and agents in transitive expressions, but it is compatible with $S E$ anticausatives. These observations are the crucial pieces of the puzzle that need to be put together in order to solve the initial problem concerning the reason why certain object experiencers combine with instrumental case-marked bare NPs while others combine with $\operatorname{od}($ 'from')-PPs under anticausativization. The goal of the next section will be to account for this observation.

\section{Putting the pieces back together}

With regard to the licensing of instrumental NPs, we cannot assume that they are simply licensed by the presence of $v^{0}$ (CAUSE), because then, we would wrongly predict their grammaticality with typical anticausatives (29) (it is standardly assumed that anticausatives contain the $v$ layer, see von Stechow 1996).

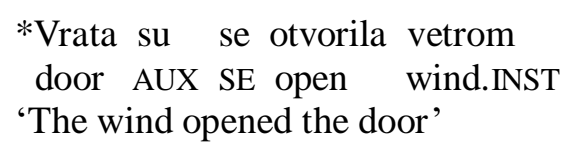


The only option that seems to be left is to assume that instrumental NPs are always licensed by Voice ${ }^{0}$ while $o d$ ('from')-PPs are ruled out by Voice ${ }^{0} .{ }^{4}$ However, we cannot say that the Voice ${ }^{0}$ that licenses instrumentals and rules out $o d($ 'from')-PPs in (30) is a typical Voice ${ }^{0}$ introducing an agent because this would give us either a reflexive/agentive reading of the sentence or it would license the presence of a by-phrase as with passives, both contrary to fact (30 and 31).

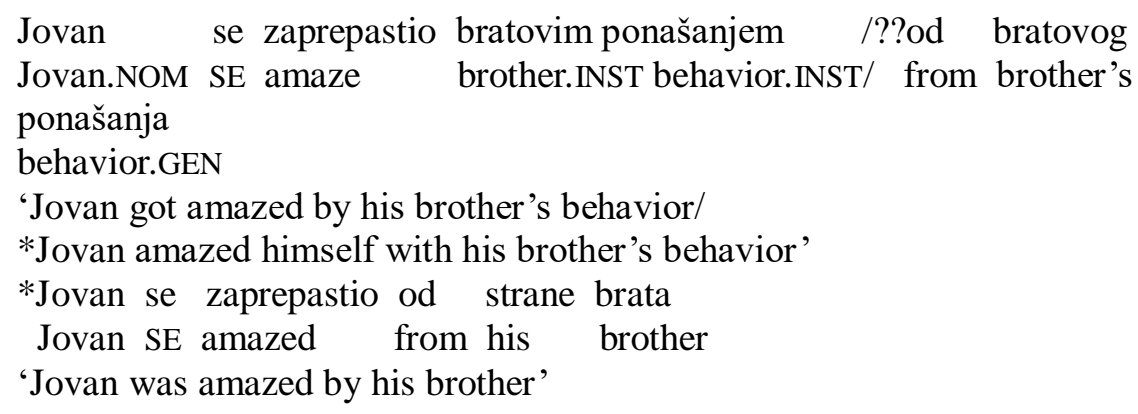

Instead, I would propose that what we have with these SE forms that license instrumental and reject $o d$ ('from')-PPs is, indeed, a Voice ${ }^{0}$ but it is the type of Voice ${ }^{0}$ that signals precisely the lack of agent. Schäfer \& Vivanco (2016) argue that the semantics for the causative alternation of the verb open (32b) is different from the semantics of its transitive counterpart (32a), in that it simply lacks the causer argument. Their argument, contra Chierchia (2004), is that $S E$ anticausatives have the same semantics as the causative alternation.

$$
\begin{array}{ll}
\text { a. } & \lambda \mathrm{x} \lambda \mathrm{y}[(\mathrm{y}) \text { CAUSE [BECOME }[(\mathrm{x}) \text { open }]]] \\
\mathrm{b} . & \lambda \mathrm{x}[\mathrm{BECOME}[(\mathrm{x}) \text { open }]]
\end{array}
$$

Let us assume with Schäfer \& Vivanco (2016) that $S E$ does have the function to eliminate the external argument. One way we could implement that without violating the Monotonicity Hypothesis (Koontz-Garboden 2007; 2009; 2012) would be by saying that $S E$ is a special type of $\mathrm{v}^{0}$ which competes with the causative $\mathrm{v}^{0}$. In contrast to the causative $\mathrm{v}^{0}$, the non-causative $\mathrm{v}^{0}$ realized as SE would not have a Spec position, which is how the external argument would be blocked. Suppose, however, that $S E$ can be a Specless $\mathrm{v}^{0}$ or a Spec-less Voice ${ }^{0}$ with its semantic contribution being merely to signal the lack of causer or agent, respectively. One interesting consequence of this position would be that we could make room for a middle ground option between Chierchia's (2004) proposal and Schäfer \& Vivanco's (2016) approach. In the situation where SE acts as a Spec-less VoiceP projected on top of $v \mathrm{P}$, there would be a full causative $v \mathrm{P}$ with a Spec position underneath. This is significant because this Spec $v \mathrm{P}$ position could now be filled by the experiencer argument to produce the structure in (33).

\footnotetext{
${ }^{4}$ The idea that VoiceP and $\mathrm{vP}$ are two separate layers of structure has recently been adopted in a number of works (Harley 2013, Bruening 2014, Merchant 2008, etc.).
} 
(33)

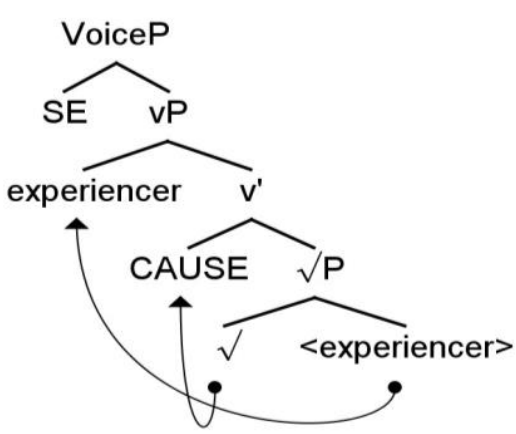

As is apparent from the tree diagram in (33), this is a structure where the experiencer argument has moved from its original position in the complement of $\sqrt{ } / \mathrm{VP}$ to Spec vP. This would give rise to a quasi-reflexive interpretation where the experiencer is also simultaneously the causer of the mental state denoted by the verb, but there is no agent. Note that this would correspond to Chierchia's (2004) reflexive-like semantics for anticausatives. This is the structure that I propose for (30) with VoiceP licensing the instrumental NP and rejecting the $o d$ ('from')-PP. Note that this special type of Voice head that signals the lack of the agent argument would semantically reject the $b y$-phrase as shown in Section 3 (ex. 13) because the by-phrase expresses an agent while the Voice ${ }^{0}$ realized as SE means that there is no agent.

The situation where SE merges as the Spec-less $v^{0}$ would correspond to a pure anticausative with the semantics in (32b) proposed by Schäfer \& Vivanco (2016). Structurally, this would amount to (34). This would be the proposed structure for (24b) repeated here as (35) where the absence of VoiceP means that there is no clash with the $o d$ ('from')-PP but at the same time an instrumental NP cannot be licensed.
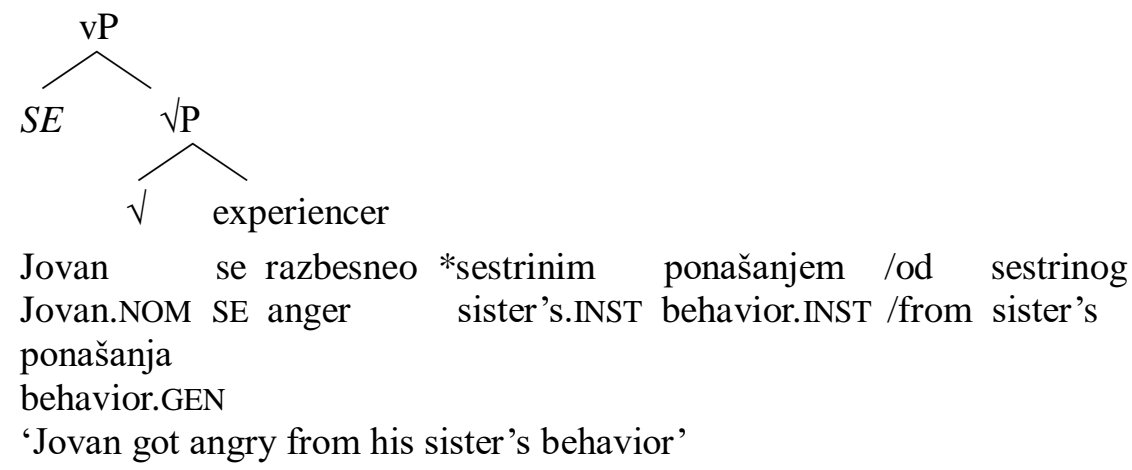

Of course, the same structure would explain the identical behavior of typical anticausatives (36).

(36) Vrata su se otvorila od vetra /*vetrom door AUX SE opened from wind.GEN/ wind.INST

'The door opened from the wind' 
The crucial question at this point would be whether there is any reason to treat structures like (30) as semi-reflexive. I would argue that there is. Schäfer \& Vivanco (2016) object to Chierchia's (2004) reflexive analysis of anticausatives on the grounds that it would lead to self-contradictory denotations for anticausative examples such as (37). If we were to assign a reflexive-like semantics to (37), we would get a denotation where a gap caused itself to open or come to existence. However, it is, of course, logically impossible for a thing to bring itself into existence.

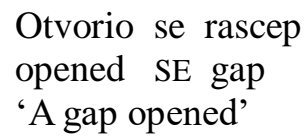

I agree with their position in this regard, which is why a semantics like the one in (32b) and a structure like the one in (34) should apply to these examples. More broadly, it is generally hard to apply a reflexive semantics to inanimates even when there is no clear contradiction of the kind in (37). But, the structure in (33) with the semantics along the lines of Chierchia (2004) was proposed here for certain psych verbs where it makes sense to assume that the experiencer can be the cause of his or her own mental state. Talmy (1988) points to examples such as (38) where it is clear that the way we conceptualize mental processes is often in the form of two parts of the psyche acting on one another.

$$
\text { I held myself back from responding. }
$$

The reason why a reflexive is used in (38) is because the central part of the psyche is seen as acting against an impulse coming from the peripheral part. In this example, the subject is also an agent because he or she acts consciously and intentionally to resist the urge to respond. Talmy (1988) points out that agency (conscious control/intentionality) is part of the central part of the psyche. It is possible, however, to imagine the opposite situation where the peripheral part of the psyche causes a certain change in the central part. It is important to note that under Talmy's (1988) model this would not be an agentive situation and so it could not be expressed with a reflexive construction because the peripheral part of the psyche is not the locus of agentivity (even though it can obviously act as a causer). One possible example of such a situation would be (39), which corresponds to (30) in Serbian, i.e. the example for which I proposed the semi-reflexive structure in (33). On a side note, the English example involving an adjectival construction with the auxiliary verb get also licenses the by-phrase, which is generally assumed to be licensed by VoiceP (Bruening 2014).

I got amazed by my friend's behavior.

In sum, the way we conceptualize psychological dynamics and encode it linguistically clearly makes room for more complex causal relations from what is observed with typical anticausatives with inanimate themes. My argument is that the reflexive-like semantics that Chierchia (2004) proposes for all anticausatives is perhaps not applicable across the board, but it would certainly make sense for psych verb 
anticausatives, and it can be attributed to the structure in (33). The structure in (33) (i.e. the presence of VoiceP) gives us an account of why these anticausative forms license instrumental NPs and reject $\operatorname{od}($ 'from')-PPs.

The question that has not been answered concerns the reason why we observe this division within the class of object experiencers in the first place. In other words, it is not clear why the anticausative form of the verb razbesneti 'anger' would have the structure in (34) as opposed to the anticausative form of the verb zaprepastiti 'amaze', which has the structure in (33).

A potential answer to this question could be related to the fact that the verb razbesneti 'anger' and related verbs allow the target $\theta$-role to be expressed by means of a directional PP (40a). This is not possible with verbs like zaprepastiti 'amaze' (40b).
a. Jovan se razbesneo na brata
Jovan SE angered at brother. ACC
'Jovan got angry at his brother'
b. *Jovan se zaprepastio na brata Jovan SE amazed at brother

A proper analysis of this discrepancy goes beyond the scope of this paper, but instead of leaving this question completely for further research, I will briefly sketch the direction that further investigation can take. Namely, my hypothesis here is that the thematic role of the experiencer argument at the level of $\sqrt{\mathrm{P}}$ is not identical with these two classes of verbs. While the experiencer is a proper theme of the verb like zaprepastiti 'amaze' in the sense of merely being affected by the mental state denoted by the verb, the experiencer argument of razbesneti 'anger' also projects the mental state outward towards some kind of target as evidenced by the contrast in (40). In that sense, at the $\sqrt{\mathrm{P}}$ level, the latter kind of verb is to be seen as expressing something like the semantics of internal causation (Levin \& Rappaport Hovav 1995). This difference is perhaps also responsible for the stark contrast in the possibilities of forming passives from these two kinds of verbs, as seen in (41):

$$
\begin{array}{ll}
\text { a. } & \text { *Jovan je razbešnjen } \\
\text { Jovan AUX angered } \\
\text { 'Jovan was angered' } \\
\text { b. Jovan je zaprepašćen } \\
\text { Jovan AUX amazed } \\
\text { 'Jovan was amazed' }
\end{array}
$$

Thus, maybe the inability of this verb (and related verbs) to assume the reflexivelike construction proposed in (33) is related to the fact that the internal argument of these verbs is not a typical theme as suggested by (40a) and (41a). Nonetheless, all these matters will have to be left for future work. 


\section{Conclusions}

This paper addressed the distribution of instrumental case-marked bare NPs and $o d$ ('from')-PPs expressing the stimulus participant with SE anticausatives derived from psych verbs in Serbian. It was observed that object experiencers can be divided into three classes when it comes to the morphosyntactic properties of the expressions introducing the stimulus participant in their $S E$ form. One class of verbs introduce this participant in the form of an instrumental case-marked bare NP (e.g. zaprepastiti se 'dazzle'). One set of verbs license $o d$ ('from')-PPs (e.g. razbesneti se 'anger'). The third class of verbs license instrumental case-marked bare NPs while simultaneously triggering a reflexive interpretation (e.g. osramotiti se 'embarrass'). Since the latter group does not involve anticausative semantics, these verbs were not investigated further here. Also, there were some verbs whose $S E$ forms seem to license both $\operatorname{od}$ ('from')-PPs and instrumental casemarked bare NPs with slight semantic differences. It was assumed that these verbs simply alternated between the first two classes so the focus was on understanding the syntactic and semantic properties of these two general types.

The differences in terms of instrumental NP/od('from')-PP licensing with $S E$ anticausatives were taken as signals of underlying structural differences. The complementary distribution of these forms was attributed to their common link with VoiceP such that instrumental NPs are licensed by VoiceP while od('from')-PPs are rejected by VoiceP as their semantics clashes with the semantics of this layer of verbal structure. In structural terms, $S E$ anticausatives that license instrumental NPs were analyzed as projecting a full $v \mathrm{P}$ and a Spec-less VoiceP on top of it with the experiencer argument moving from the complement position of the root/VP to Spec $v \mathrm{P}$. In contrast, verbs that license $o d($ 'from')-PPs while rejecting instrumental NPs were analyzed as typical anticausatives with a Spec-less $v \mathrm{P}$.

One important implication of this analysis relates to the debate about the syntactic and semantic contribution of the SE morpheme. It was argued that the analysis established here steers a middle course between Chierhcia's (2004) reflexive approach to $S E$ anticausatives and what Schäfer \& Vivanco (2016) call the "standard approach", which is basically the view that SE signals the lack of external argument. The analysis developed in this paper treats "typical" SE anticausatives with inanimate internal arguments and those psych verb anticausatives that license $\operatorname{od}$ ('from')-PPs in accordance with the standard approach, thus avoiding some of the issues of Chierchia's (2004) analysis outlined by Schäfer \& Vivanco (2016). At the same time, the reflexive-like analysis of $S E$ with anticausatives is retained for psych verbs that license instrumental NPs, where the same issues do not arise, as I have argued drawing on Talmy's (1988) work on force dynamics.

\section{References}

Alexiadou, A., Anagnostopoulou, E. \& Schäfer, F. 2009. PP licensing in nominalizations. In A. Schardi, M. Walkow \& M. Abdurrahman (eds.), NELS 38: Proceedings of the 38th Annual Meeting of the North East Linguistic Society, 39-52. Amherst, MA: GLSA.

Alexiadou, A. \& Iordăchioaia, G. 2014. The psych causative alternation. Lingua 148: 53-79.

Alexiadou, A., Iordăchioaia, G., Cano, M., Martin, F., \& Schäfer, F. 2013. The realization of external arguments in nominalizations. The Journal of Comparative Germanic Linguistics 16 (2-3): 73-95. 
Anagnostopoulou, E., \& Samioti, Y. 2014. Domains within words and their meanings: A case study. In A. Alexiadou, H. Borer \& F. Schäfer (eds.), The Syntax of Roots and the Roots of Syntax, 81-111. Oxford: Oxford University Press.

Baker, M. C. 1988. Incorporation: A Theory of Grammatical Function Changing. Chicago: University of Chicago Press.

Belletti, A., \& Rizzi, L. 1988. Psych-verbs and $\theta$-theory. Natural Language \& Linguistic Theory 6 (3): 291-352.

Bošković, Ž. 2005. On the locality of left branch extraction and the structure of NP. Studia linguistica, 59 (1): $1-45$.

Bošković, Ž. 2012. On NPs and clauses. In G. Grewendorf \& T. E. Zimmermann (eds.), Discourse and Grammar: From Sentence Types to Lexical Categories, 179-247. Boston/Berlin: Walter de Gruyter.

Bruening, B. 2014. Word formation is syntactic: Adjectival passives in English. Natural Language \& Linguistic Theory 32 (2): 363-422.

Chierchia, G. 2004. A semantics for unaccusatives and its syntactic consequences. In A. Alexiadou, E. Anagnostopoulou \& M. Everaert (eds.), The Unaccusativity Puzzle: Explorations of the SyntaxLexicon Interface, 22-59. Oxford: Oxford University Press.

Chomsky, N. 1993. Lectures on Government and Binding: The Pisa Lectures, seventh edition. Boston: Walter de Gruyter.

Doron, E. 2014. The interaction of adjectival passive and voice. In A. Alexiadou, H. Borer \& F. Schäfer (eds.), The Syntax of Roots and the Roots of Syntax 164-192. Oxford: Oxford University Press.

Gehrke, B. 2013. Still puzzled by adjectival passives? In R. Folli, C. Sevdali \& R. Truswell (eds.), Syntax and its Limits, 175-192. Oxford: Oxford University Press.

Halle, M. \& Marantz, A. 1993. Distributed Morphology and the pieces of inflection. In K. Hale \& S. J. Keyser (eds.), The View from Building 21, 111-176. Cambridge, MA: MIT Press.

Harley, H. 2013. External arguments and the Mirror Principle: On the distinctness of Voice and v. Lingua 125: 34-57.

Koontz-Garboden, A. 2007. States, changes of state, and the Monotonicity Hypothesis. PhD dissertation, Stanford University.

Koontz-Garboden, A. 2009. Anticausativization. Natural Language and Linguistic Theory 27: 77-138.

Koontz-Garboden, A. 2012. The monotonicity hypothesis. In L. McNally \& V. Demonte (eds.), Telicity, Change and State. A Cross-Categorial View of Event Structure, 139-161. Oxford: Oxford University Press.

Kratzer, A. 1996. Severing the external argument from its verb. In J. Rooryck \& L. Zaring (eds.), Phrase Structure and the Lexicon 109-137. Dordrecht: Kluwer Academic Publishers.

Kratzer, A. 2000. Building statives. In L. Conathan, J. Good, D. Kavistkaya, A. Wulf \& A. Yu, (eds.), Proceedings of the Berkeley Linguistic Society, 385-399. Berkeley: Berkeley Linguistics Society.

Landau, I. 2010. The Locative Syntax of Experiencers. Cambridge, MA: MIT Press.

Levin, B. 1993. English Verb Classes and Alternations: A Preliminary Investigation. University of Chicago Press.

Levin, B., \& Rappaport Hovav, M. 1995. Unaccusativity. Cambridge, MA: MIT Press.

Marelj, M. 2004. Middles and Argument Structure across Languages. PhD dissertation, Netherlands Graduate School of Linguistics.

Merchant, J. 2008. An asymmetry in voice mismatches in VP-ellipsis and pseudogapping. Linguistic Inquiry 39 (1): 169-179.

Pesetsky, D. M. 1996. Zero Syntax: Experiencers and Cascades. Cambridge, MA: MIT press.

Piper, P., Antonić, I., Ružić, V., Tanasić, S., Popović, L. \& Tošović, B. 2005. Sintaksa savremenoga srpskog jezika: prosta rečenica. Belgrade: Institute for Serbian Language of the Serbian Academy of Arts and Sciences.

Ramchand, G. C. 2008. Verb Meaning and the Lexicon: A First Phase Syntax. Cambridge: Cambridge University Press.

Reinhart, T. 2000. The Theta System: Syntactic realization of verbal concepts. OTS Working Papers.

Reinhart, T. 2003. The Theta System: An overview. Theoretical Linguistics 28 (3): 229-290.

Schäfer, F., \& Vivanco, M. 2016. Anticausatives are weak scalar expressions, not reflexive expressions. Glossa: A Journal of General Linguistics 1(1), 18. http://doi.org/10.5334/gjgl.36.

Talmy, L. 1988. Force dynamics in language and cognition. Cognitive science 12 (1): 49-100.

von Stechow, A. 1996. The different readings of wieder 'again': A structural account. Journal of Semantics 13 (2): 87-138.

Wolff, P. 2003. Direct causation in the linguistic coding and individuation of causal events. Cognition 88 (1): $1-48$. 